\title{
PENYELESAIAN SENGKETA WAKAF DI INDONESIA: Pendekatan Sejarah Sosial Hukum Islam
}

\author{
Ibrahim Siregar \\ Jurusan Syariah STAIN Padangsidimpuan \\ Jl. Imam Bonjol Km. 4, 5 Sihitang Padangsidimpuan, 22726 \\ e-mail: himregar@yahoo.com
}

\begin{abstract}
Abstrak: Artikel ini berbicara tentang penyelesaian sengketa wakaf dalam sejarah hukum Islam. Permasalahan wakaf telah muncul di awal sejarah Islam. Sehubungan dengan sengketa tentang status harta sebagai wakaf telah muncul pada masa lalu disebabkan oleh perubahan sosial; pergeseran nilai dan tatanan masyarakat, dan ditambah lagi dengan masalah bahwa tidak adanya bukti tertulis yang menyatakan bahwa status suatu harta sebagai objek wakaf. Pada tulisan ini dikemukakan kasus-kasus permasalahan sengketa wakaf yang terjadi pada awal periode Islam dan kasus-kasus kontemporer tentang sengketa perwakafan serta penyelesaiannya, yang terjadi di Indonesia pada beberapa dasawarsa yang lalu.
\end{abstract}

\begin{abstract}
The Settlement of Religious endowment (waqf) Dispute: A Socio-Historical Approach of Islamic law. This paper concentrates on the settlement of religious endowment (waqf) dispute in the perspective of Islamic law history. The disputes relating to waqf has emerged since the early development of Islamic history. In regard with the conflict of the status of waqf property, the disputes have originated from the social change, the shift of values in the society, and the absence of written evidence of waqf property. This article will elaborate the cases of waqf disputes which occured in the early periods of Islam and the contemporery cases along with the settlement of the disputes taking place in Indonesia in the last few decades.
\end{abstract}

Kata Kunci: Hukum Islam, Hukum Perwakafan, Sejarah Sosial Hukum Islam

\section{Pendahuluan}

Sebelum membicarakan penyelesaian sengketa wakaf dalam sejarah hukum Islam, terlebih dahulu dikemukakan gambaran konflik dan penyelesaiannya dalam masyarakat Islam. Dalam perkembangannya, masyarakat Islam tidak terlepas dari ciri dinamika sosial yang memiliki proses sosial. Salah satu proses sosial tersebut adalah terjadinya kompetisi dalam memperoleh suatu nilai, yang terkadang dapat mencapai puncak eskalasi ke tahap 
konflik. Paul Bohanan salah seorang pakar sosiologi mengatakan bahwa pada satu sisi, sesuatu yang ekstrem apabila tidak ada konflik dalam suatu masyarakat, tetapi di sisi lain adalah bahwa sesuatu yang ekstrem pula apabila suatu konflik tidak dapat diselesaikan. ${ }^{1}$ Dengan demikian, konflik sebagai suatu yang tidak terpisahkan dalam suatu masyarakat akan mengalami permasalahan serius apabila tidak dapat diselesaikan, yang pada akhirnya dapat mengakibatkan hilangnya keseimbangan (instability) atau kedamaian dalam masyarakat. Dalam sejarah hukum Islam, penyelesian konflik pada masyarakat diselesaikan untuk mengembalikan stabilitas sosial dengan cara yang variatif, seperti melalui hakam dan peradilan.

\section{Penyelesaian Sengketa dalam Sejarah Hukum Islam}

\section{Konsep Hakam dalam Fikih Islam}

Karena hakam adalah suatu peran yang tidak terlepas dari pelaksanaan proses tahkîm, maka untuk memahami makna terminologi hakam perlu terlebih dahulu dipahami arti istilah tahkkîm tersebut. Adapun tahkkîm menurut terminologi fikih adalah "adanya dua orang atau lebih yang meminta kepada orang lain agar memberi keputusan terhadap perselisihan yang terjadi di antara mereka berdasarkan hukum syar ' $\hat{\imath} . " 2$

Dasar hukum takîm dalam Islam adalah firman Allah dalam al-Qur'an Surah alNisâ'/4: 35 yang artinya "Dan jika kamu khawatir ada persengketaan antara keduanya, maka kirimlah seorang hakam dari keluarga laki-laki dan seorang hakam dari keluarga perempuan. Jika kedua orang hakam itu bermaksud mengadakan perbaikan, niscaya Allah memberi taufik kepada suami istri itu."

Ayat tersebut di atas menjelaskan tentang syiqâq, yaitu perselisihan yang meruncing antara suami istri yang diselesaikan oleh dua orang juru damai (hakam). Ayat ini menganjurkan adanya pihak ketiga atau mediator yang dapat membantu pihak suami dan istri dalam mencari solusi penyelesaian sengketa keluarga mereka. Masing-masing pihak mempunyai wakil yang berperan sebagai mediator.

Dari ayat tersebut dapat dengan jelas dipahami bahwa al-Qur'an menggunakan term hakam untuk mediator atau arbiter. Menurut ayat tersebut bahwa mediator yang bertindak sebagai pencari solusi terhadap masalah keluarga tersebut memiliki peran penting dalam menangani konflik antara suami istri.

Sehubungan dengan siapa yang menunjuk dan mengutus hakam atau mediator dalam perselisihan syiqâq terjadi silang pendapat di antara ulama fikih. Menurut ulama fikih kontemporer Wahbah Zuhayli dan Sayyid Sabiq, hakam dapat diangkat oleh suami istri dari orang yang

${ }^{1}$ Paul Bohanan, Law and Warfare Studies in the Anthroplogy of Conflict (New York: The Natural History Press, 1967), h. 8.

${ }^{2}$ Samir Aliyah, Nizhâm al-Daulah wa al-Qadhâ' wa al-'Urffí al-Islâm (Jakarta Timur: Khifa, 2004), h. 328. 
mereka setujui sebagai mediator yang akan membantu mereka dalam mencari solusi terhadap percekcokan dalam rumah tangga mereka. Sementara ulama mazhab Hanafi, Syâfiî̀, dan Hanbali berpendapat bahwa berdasarkan lahir ayat 35 surat al-Nisâ' bahwa hakam atau mediator diangkat oleh pihak keluarga suami atau istri, dan bukan suami atau istri secara langsung. ${ }^{3}$

Dalam fakta sejarah hukum Islam bahwa tahkim bukanlah terbatas hanya merupakan penyelesaian sengketa keluarga antara suami istri sebagaimana yang dijelaskan oleh ayat tersebut di atas. Praktik tahkîm ini telah diperankan oleh Muhammad SAW. dalam banyak kasus persengketaan, dan beliau mengatakan bahwa betapa bagusnya tahkkîm tersebut dilakukan. Hal ini beliau sabdakan dalam merespons Abû Syuraih ketika berkata, "Sesungguhnya kaumku jika berselisih tentang sesuatu maka mereka datang kepadaku, lalu saya putuskan di antara mereka, dan kedua pihak rida atas putusanku."4

\section{Lembaga Peradilan sebagai Lembaga Penyelesaian Sengketa dalam Islam}

Dalam penegakan keadilan, khususnya pada penyelesaian persengketaan pada periode kenabian, Nabi Muhammad SAW. berperan melaksanakan tugas sebagai penegak keadilan di samping berfungsi sebagai kepala negara. Praktik seperti ini, yakni sebagai kepala negara atau gubernur sekaligus sebagai hakim berlangsung selama periode beliau. Kemudian untuk penegakan keadilan setelah ekspansi wilayah Islam semakin luas kebijakan baru dilakukan oleh Nabi dengan penugasan para hakim ke berbagai daerah untuk menyelesaikan sengketa yang terjadi pada masyarakat Islam.

Di antara hakim-hakim yang diutus Nabi Muhammad ke daerah-daerah pemerintahan Islam adalah 'Ali ibn Abî Thâlib dan Ma'qal ibn Yasar serta Mu'adz ibn Jabal ke Yaman. Kemudian Utab ibn Asid sebagai gubernur dan hakim di Makkah setelah peristiwa penaklukan Makkah.

Para Khalifah Rasyidun mengutus para sahabat yang layak menjadi hakim karena baik pemahaman agamanya. Mereka ditugaskan untuk menyelesaikan masalah-masalah masyarakat di negara-negara yang baru tertaklukkan dan menjadi bagian baru dari negara Islam. Hal ini dilakukan untuk memberikan kemudahan bagi masyarakat Islam dalam rangka pencarian keadilan karena munculnya persengketaan di antara mereka.

Praktik yang demikian berlangsung lama dan berlanjut hingga masa khilafah Usmaniyah. Pada masa khilafah ini pendapat ahli fikih mengalami perkembangan seperti munculnya pandangan hukum kebolehan menempatkan hakim khusus sesuai dengan jenis kasus persengketaan. Demikian juga bolehnya menentukan masing-masing hakim untuk bertugas pada waktu, tempat dan untuk pengikut mazhab tertentu. Penguasa juga boleh menempatkan hakim khusus untuk menangani segala bentuk kasus yang sering diajukan seperti pengangkatan

${ }^{3}$ Syahrizal Abbas, Mediasi dalam Perspektif Hukum Syariah, Hukum Adat, dan Hukum Nasional (Jakarta: Kencana Prenada Media Group, 2009), h. 185-189.

${ }^{4}$ Samir 'Aliyah, Nizhâm al-Daulah wa al-Qadhâ', h. 328. 
hakim yang khusus menangani sengketa keluarga, atau kasus gugatan perdata lainnya, seperti perdagangan atau kasus sosial yang lain sebagainya. ${ }^{5}$

Selanjutnya, peradilan pada masa Bani Umaiyah memiliki dua karakteristik keistimewaan. Pertama, berlangsunya peradilan seperti pada masa Khalafâ' Râsyidîn, yaitu bahwa hakim berijtihad dan menetapkan hukum dengan hasil ijtihadnya tersebut. Ijtihad tersebut dilakukan apabila hakim tidak menemukan nashsh dan ijmấ pada masa sebelumnya yang berkaitan dengan kasus yang dihadapai. Kedua, peradilan tidak terpengaruh oleh politik. Dengan demikian, para hakim bersifat independen tanpa terpengaruh dengan keinginan pemerintah yang sedang berkuasa. Mereka bebas dalam bersikap, dan pendapat mereka dilaksanakan hingga terhadap para pejabat tinggi negara. ${ }^{6}$

Pada masa ini dikenal pencatatan hukum dalam catatan khusus. Adapun orang yang pertama melakukan hal tersebut adalah Sulaim ibn 'Itr, seorang hakim di Mesir pada masa Mu'âwiyah ibn Abî Sufyân. Ketika itu, dia memutuskan tentang perkara warisan yang dipersengketakan oleh ahli waris. Ketika diberi keputusan mereka menolak keputusan hakim Sulaim tersebut. Kemudian, mereka kembali datang kepadanya untuk kalinya, sehingga memberikan keputusan hukum bagi mereka dan keputusan hukum tersebut dicatat dalam buku khusus. Inilah keputusan hukum yang pertama dicatat dalam peradilan Islam.

Peradilan pada masa pemerintahan 'Umar ibn 'Abd al-Azîz, salah seorang khalifah dinasti Umaiyyah, mengalami kemajuan yang signifikan dalam memberantas kezaliman yang terjadi pada masa dinasti tersebut berkuasa. Di antara pekerjaan utama yang dilakukan 'Umar ibn 'Abd al-Azîz adalah pemecatan para gubernur yang zalim. Beliau menetapkan syarat-syarat yang jelas untuk jabatan hakim demi penegakan keadilan. Ketika gubernur di Khurasan mengirimkan surat kepadanya bahwa kaum tidak cukup diberikan peringatan melainkan dengan cambuk dan pedang, maka ia menjawab, "Engkau bohong, mereka dapat menjadi baik dengan keadilan dan kebenaran, maka tegakkanlah hal tersebut kepada mereka." Ia juga mengatakan, "Jangan sekali-kali kamu memukul orang yang beriman dan kafir dzimmî melainkan dengan alasan yang benar, dan hindarilah qishâsh."

Pada masa pemerintahan Bani 'Abbâs, peradilan memiliki dinamikanya yang berbeda pula. Pada masa ini pembangunan meningkat pesat, Islam semakin tersebar, aktivitas keilmuan, ekonomi dan sosial semakin bertambah, munculnya perdebatan fikih dengan berdirinya empat mazhab, munculnya tradisi taklid, melemahnya semangat semangat ijtihad, dan perbedaan hukum para hakim. Penetapan hukum di Irak sesuai mazhab dan Maroko dengan mazhab Mâliki, dan di Mesir dengan mazhab Syâfiî̀. Jika dua orang yang bersengketa datang untuk mencari solusi, dan mereka dari selain mazhab yang berlaku di daerah tersebut, maka hakim yang resmi digantikan oleh hakim lain yang memutuskan hukum sesuai dengan mazhab dua orang yang bersengketa tersebut.

${ }^{5}$ Muhammad Abid Abdullah al-Kabisi, Ahkhâm al-Waqfî̀ al-Syarî‘ah al-Islâmiyah (Jakarta: Dompet Dhuafa dan IIMan, 2004), h. 554-562.

${ }^{6}$ Samir Aliyah, Nizhâm al-Daulah wa al-Qadhâ', h. 309. 
Pada masa pemerintahan dinasti ini ada intervensi dari pihak oknum penguasa dalam pelaksanaan peradilan. Karena sebagian khalifah Abbasiyah ikut campur tangan dalam kemerdekaan peradilan, maka hal ini membuat para fakih menolak jabatan hakim peradilan

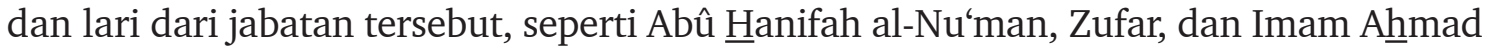
ibn $\underline{\text { Hanbal. }}$

Pada masa ini, dibentuk jabatan baru dalam peradilan, yaitu hakimnya para hakim yang ditunjuk dalam jabatan ini adalah Abû Yûsuf, yang mendapat julukan Qâdhî alQudhât. Ia berperan menangani penentuan para hakim, pemecatan hakim serta mengawasi sikap dan tindakan mereka. Ia adalah orang pertama menetapkan para hakim dengan pakaian khusus yang membedakan dengan masyarakat lain.

Selanjutnya, peradilan daulah Usmaniyah di Lebanon memiliki karakteristik sendiri pula. Ketika daulah Usmaniyah berdiri pada awal abad XIV M., negara-negara Arab ketika itu, termasuk Syiria dan Lebanon tunduk kepada syariat Islam sebagai undang-undang umum, dan para hakim secara umum membentuk mahkamah biasa. Kondisi ini bertahan hingga abad XVI, ketika Turki mengambil alih kekuasaan secara bertahap, dan wilayah Syiria tunduk kepada mereka pada tahun $1516 \mathrm{M}$.

Sistem peradilan di masa ini adalah dengan bentuk sebagai berikut. Kekuasaan peradilan pada mulanya adalah di tangan para tokoh agama, kemudian pemerintah menguasai pemerintahan di daerah dan termasuk peradilan. Peradilan kemudian dilaksanakan sendiri atau didelegasikan kepada wakil yang berasal dari kalangan sekuler dan tokoh agama. Pada dasarnya, otoritas pemerintah adalah sampai penetapan dan pengangkatan seseorang untuk jabatan hakim dalam rangka penegakan hukum dengan penerapan pasal-pasal hukum yang telah mereka tetapkan untuk kemaslahatan mereka atau kemaslahatan pemilik keputusan. Hal ini berlangsung hingga tahun 1745.

Para hakim ketika itu, dalam memutuskan perselisihan adalah dengan menerapkan adat dan tradisi. Ketika Basyir al-Syihâbî memegang pemerintahan, maka dia mengubah sistem peradilan dengan memasukkan hukum-hukum Islam yang tertulis dan mewajibkan berpegang kepada fikih Islam. Tetapi, sistem ini memunculkan sanggahan dari sebagian tokoh kelompok al-Marûniyah di Kiswarawan karena kontradiksinya sistem ini dengan sebagian nilai-nilai tradisi yang sejak lama berlaku di wilayah tersebut. Seperti tradisi yang menetapkan terhalangnya anak perempuan dari warisan dan membatasi haknya dengan mas kawin atau pemberian.

Kemudian pada tahun 1842, Lebanon terjadi menjadi dua bagian. Amîr Basyir menentukan di kedua wilayah tersebut seorang hakim bagi kaum Nasrani dan seorang hakim bagi kaum Darwis, kemudian menetapkan sistem baru pada tahun 1846. Ia membuat suatu majelis untuk al-Muwaranah dan majelis untuk Darwis di setiap wilayah; masing-masing dari dua majelis ini memutuskan perkara berdasarkan tradisi lokal. Sedangkan perkara-perkara yang khusus dengan masing-masing kelompok, maka hukumnya diputuskan oleh hakim atau penasihat yang berafiliasi kepada kelompok tersebut, sedangkan anggota majelis yang lain hanya mendengarkan saja. 
Di Irak, peradilan dilakukan dengan menempatkan kasus sengketa sesuai dengan pembagian lembaga peradilan serta menetapkan struktur lembaga peradilan tersebut. Perkembangan pemikiran tersebut pada puncaknya menjelma menjadi undang-undang khusus yang membagi struktur peradilan (mahkamah) menjadi beberapa bagian dan tingkatan. Setiap struktur untuk menangani satu jenis kasus saja sebagai berikut: Mahkamah Perundang-undangan, Mahkamah Syariah, Mahkamah Niaga. Tingkatan di atas lembagalembaga peradilan tersebut secara struktural adalah Mahkamah Banding, Mahkamah Kasasi, dan Mahkamah Agung.

Pada masa ini, Mahkamah Syariah memiliki salah satu tugas khususnya untukmenyelesaikan sengketa perwakafan. Mahkamah ini mengawasi sah atau tidaknya gugatan persengketaan perwakafan dan gugatan yang berkenaan dengan pengawasan harta wakaf baik yang berbentuk musaqqafât (real estate) maupun mustaghallât (segala harta benda wakaf yang diambil manfaatnya) yang dipandang ulama sebagai harta wakaf yang sah menurut syariah. ${ }^{7}$

Pasal 15 Undang-Undang Mahkamah Syariah tahun 1923 tentang Perwakafan Irak memuat aturan bahwa Pengadilan khusus yang berkaitan dengan pemeriksaan terhadap persoalan-persoalan yang berkenaan dengan kelayakan pewakaf, rukun wakaf, syaratsyarat wakaf, pemberian kuasa pengelolaan, orang yang berhak menerima wakaf dan cara pemanfaatan harta wakaf serta lainnya merupakan kompetensi Mahkamah Syariah. Demikian juga bahwa hak khusus bagi Mahkamah Syariah adalah segala kasus yang berkenaan dengan perubahan wakaf. Mahkamah Syariah juga berhak menangani kasus gugatan sengketa yang berkenaan dengan hukum asal wakaf dan syarat-syaratnya hingga kemudian dikeluarkan penjelasan peraturan dari undang-undang prosedur hukum syariat No. 5 tahun 1929. Dalam hal ini pengadilan tingkat pertama diikutsertakan dalam menangani kasus gugatan pengawasan wakaf atas kesepakatan kedua pihak yang bersengketa.

Selanjutnya, di Indonesia pasal 10 Undang-Undang No. 14 tahun 1970 tentang PokokPokok Kekuasaan Kehakiman menjelaskan bahwa yang dimaksud dengan badan-badan peradilan tersebut adalah peradilan umum, peradilan militer dan peradilan tata usaha negara dan peradilan agama. Salah satu tugas dari badan peradilan dimaksud adalah untuk meluruskan kembali norma-norma hukum yang terlanggar. Karena dengan terlanggarnya hukum akan mengakibatkan timbulnya perselisihan-perselisihan yang akan mengakibatkan pula terganggunya efektivitas komunikasi antara sesama anggota masyarakat dan negara. Keempat badan peradilan ini dalam realisasi pelaksanaan tugasnya masing-masing mempunyai wewenang dan kompetensi tertentu. ${ }^{8}$

Kemudian, diterbitkan Undang-Undang Nomor 35 tahun 1999 tentang perubahan atas Undang-Undang Nomor 14 Tahun 1970 tentang Ketentuan-Ketentuan Kekuasaan

${ }^{7}$ Abdullah Al-Kabisi, Hukum Wakaf, h. 558.

${ }^{8}$ Taufik Hamami, Perwakafan Tanah dalam Politik Hukum Agraria Nasional (Jakarta: Tatanusa, 2003), h. 169. 
Kehakiman tersebut. Konsekuensi dari diundangkannya UU No. 35 Tahun 1999 tersebut, ditetapkan kebijakan bahwa, segala urusan mengenai peradilan baik yang menyangkut teknis yudisial maupun urusan organisasi, administrasi, dan finansial berada satu atap di bawah kekuasaan Mahkamah Agung. Dengan ditetapkannya kebijakan ini, maka lembaga-lembaga peradilan yang ada di Indonesia, Peradilan umum, Peradilan Tata Usaha Negara, Peradilan Agama, dan Peradilan Militer, segera dialihkan ke Mahkamah Agung. Kebijakan ini juga dilakukan untuk memisahkan kekuasaan eksekutif dengan yudikatif, dengan tujuan utuk memantapkan posisi lembaga peradilan pada segi-segi hukum formal dan teknis peradilan.

Sehubungan dengan Pengadilan Agama, wewenang dan kompetensinya adalah khusus untuk mengadili masalah-masalah perselisihan hukum kekeluargaan dan sebagian hukum perikatan yang memerlukan penanganan dan penyelesaian secara syariat Islam, seperti halnya masalah perkawinan dan perceraian serta hal-hal yang berhubungan dengan itu dari mereka yang beragama Islam dan masalah-masalah perikatan yang pelaksanaannya sehari-hari berdasarkan syariat Islam seperti waris-mâl dan hibah. Tetapi kompetensinya mengalami perkembanganya pada masalah-masalah ekonomi Syariah sejak diundangkannya Undang-Undang Nomor 3 Tahun 2006 tentang Peradilan Agama yang kewenangannya meliputi tentang Ekonomi Syari'ah.

Sekaitan dengan fungsi Pengadilan Agama di Indonesia, tidak dapat dipungkiri bahwa lembaga peradilan ini merupakan kebutuhan umat Islam dalam menyelesaikan masalahmasalah keperdataan Islam. Sebelum terjadinya positivisasi hukum Islam oleh pemerintah kolonial Belanda, hukum Islam telah berjalan sebagai living law di kalangan masyarakat Muslim di Nusantara ini. Peran hakim dilaksanakan oleh para ulama jauh sebelum pengadilan dilembagakan oleh pemerintah Hindia Belanda, yang mendasarkan hukum materilnya kepada fikih-fikih Klasik. Sesuai dengan paradigma aliran hukum positivisme, pemerintah kolonial Belanda membentuk peradilan formal, yang disebut dengan term yang tidak tepat, priesterraad, yang berarti pengadilan pendeta. ${ }^{9}$

Masih sehubungan dengan keberadaan peradilan agama bagi umat Islam Indonesia, dalam simpul temuan penelitiannya Jaenal Arifin menjelaskan bahwa eksistensi peradilan agama, baik status dan kedudukan, kewenangan, hukum materil, termasuk juga kebiasaan hakim dalam memutuskan perkara, lebih banyak ditentukan oleh aspek kultural daripada struktural. Kultural yang dimaksud dalam kajiannya adalah sesuatu yang secara sosiologis ada, hidup dan dilaksanakan oleh masyarakat, sedangkan struktural adalah sesuatu yang ada yang diproduk dari pengembangan, perencanaan, dan dilakukan oleh penguasa, dalam hal ini adalah pihak yang berwenang dalam menangani peradilan agama. ${ }^{10}$

${ }^{9}$ Ahmad Rofiq, Hukum Islam di Indonesia (Jakarta: PT RajaGrafindo Persada, 2000), 15.

${ }^{10}$ Jaenal Aripin, Peradilan Agama dalam Bingkai Reformasi Hukum di Indonesia (Jakarta: Prenada Media Group, 2008), h. 504-505. 
Selanjutnya, bahwa kokohnya keberadaan peradilan agama lebih disebabkan karena dorongan sosial dan budaya. Secara kultural peradilan agama merupakan sui generis bagi umat Islam Indonesia. Ia eksis karena terkait dan/atau dipengaruhi oleh kultur masyarakat Muslim Indonesia. Sepanjang masyarakat Muslim Indonesia patuh serta taat dan tunduk kepada agamanya dalam kehidupan sehari-hari, sepanjang itu pula peradilan agama akan tetap ada, meskipun seandainya pihak penguasa berusaha menghapuskan peradilan agama baik secara politis maupun hukum melalui peraturan perundang-undangan, namun Peradilan Agama akan tetap eksis.

Sekaitan dengan hukum materil pengadilan ini, kendati status dan kedudukan hukum materil bagi kewenangan peradilan agama belum kuat, akan tetapi hakim tetap bisa memutuskan persoalan hukum yang terkait dengan umat Islam yakni dengan menggunakan hukum yang hidup di masyarakat.

\section{Kasus-Kasus Sengketa Wakaf dalam Sejarah Hukum Islam}

Potensi sengketa sangat erat dengan asset wakaf. Problematika berkaitan dengan status harta wakaf telah muncul setelah Rasulullah wafat. Hal ini dapat dipahami pada kasus harta wakaf yang diberikan oleh Mukhairik kepada Rasulullah. Rasulullah menerima harta Mukhairik atas pernyataannya bahwa apabila dia terbunuh pada perang Uhud, tujuh perkebunan miliknya sendiri menjadi milik Nabi Muhammad SAW. dan terserah kepada beliau untuk dipergunakan sesuai dengan kemasalahatannnya. Rasulullah kemudian menyisihkan sebagaian hasil dari perkebunan itu untuk memberi nafkah keluarganya selama satu tahun, selebihnya digunakan untuk kepentingan kaum muslimin dan peralatan perang yang terdiri dari kuda dan senjata. Ahli fikih mengatakan bahwa harta tersebut merupakan wakaf, meskipun tidak ada kepastian apakah Rasulullah telah menetapkan perkebunan Mukhairik tersebut sebagai harta wakaf.

Namun ketika menjabat khilafah, Abû Bakar tidak menetapkan harta itu sebagai harta warisan untuk keluarga Nabi SAW., dan sebagian hasilnya tidak lagi diberikan kepada mereka. Apabila perkebunan itu merupakan wakaf, maka Abû Bakar tetap memandang statusnya wakaf dan mendistribusikan hasilnya sesuai dengan tujuan pewakaf, yaitu sebagian untuk nafkah keluarga Nabi dan selebihnya untuk kepentingan masyarakat Muslim dan peralatan perang yang terdiri dari kuda dan senjata.

Kemudian, ketika menjadi Khalifah, 'Umar memercayakan kebun tersebut kepada 'Abbâs dan Ali ibn Abî Thâlib. Karena di antara mereka berdua terjadi perbedaan pendapat, maka 'Umar menarik kembali kepengurusan harta tersebut dari mereka karena khawatir harta tersebut menjadi harta warisan. Kemudian 'Umar menetapkan harta tersebut menjadi milik bait al-mâl kaum Muslim. Dengan demikian dari kasus ini dapat dipahami bahwa terjadi perbedaan pendapat berkaitan apakah status perkebunan tersebut merupakan wakaf dari Nabi Muhammad SAW. 
Kasus serupa terjadi pada kebun Bairuha' yang diwakafkan oleh Abû Thalhah. Atas arahan Rasulullah, Abû Thalhah menyerahkan harta wakafnya tersebut kepada keluarganya.

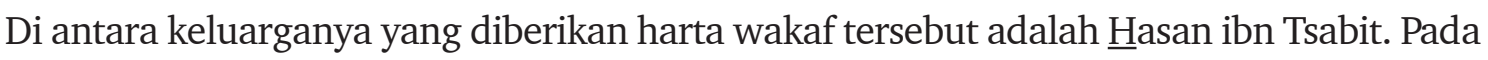
masa pemerintahan Mu'awiyah, $\underline{\text { Hasan }}$ menjual harta wakaf yang berada padanya, sehingga dikatakan kepadanya, "Apakah aku akan menjual satu gantang kurma dengan satu gantang dirham?" Kalau tanah ini merupakan harta wakaf untuk keluarga dan keturunan Abû Thalhah, maka tidakmungkin akan dijual, kecuali menurut pendapatorangyang mengatakan "sesungguhnya wakaf tetap dimiliki secara utuh oleh pemiliknya."11

Demikian perbedaan pendapat dalam permasalahan perwakafan telah terjadi di kalangan sahabat setelah Rasulullah wafat. Dalam dua kasus di atas berkaitan dengan status harta apakah wakaf atau tidak. Tentu saja hal tersebut terjadi karena tidak ada pernyataan yang jelas dan tegas oleh pemilik harta apakah status harta yang diserahkan tersebut merupakan harta wakaf supaya tidak muncul berbeda penafsiran di kemudian hari yang mungkin saja disengaja oleh pihak tertentu dengan motif nilai tertentu, ataupun tidak demikian adanya.

Tentu saja perbedaan pendapat tentang aset wakaf tersebut tidak hanya terjadinya pada masa itu, tetapi kuat dugaan bahwa perbedaan pendapat yang lebih keras hingga menjadi konflik dan memuncak menjadi sengketa (dispute) telah terjadi pada masa-masa berikutnya seiring dengan perkembangan sosial masyarakat Islam yang mengalami ekspansi wilayah dan urbanisasi yang tidak terlepas dari dinamika sosio ekonomis dan politis. Memang sudah merupakan karakter dalam proses sosial bahwa konflik harus ada dalam suatu masyarakat. Pada satu sisi merupakan hal yang ekstrem apabila di satu masyarakat tidak terjadi konflik, dan pada sisi lain, hal yang ekstrem pula apabila suatu konflik tidak dapat diselesaikan. ${ }^{12}$ Sementara sumber konflik tidak jarang karena adanya kompetisi terhadap suatu nilai, dan nilai suatu aset wakaf akan terus meningkat sering dengan dinamika masyarakat seperti urbanisasi dan perkembangan lainnya. Sebagaimana dijelaskan dalam kasus harta wakaf Abû Thalhahah berupa kebun di Bairuha', Hasan ibn Tsabit menjual harta wakaf tanpa menghiraukan norma yang melarang perbuatan penjualan harta wakaf tersebut untuk mendapat nilai ekonomis yang telah mengalami peningkatan pada masa pemerintahan Mu'awiyah.

Apabila kasus-kasus di atas merupakan peristiwa hukum persengketaan wakaf pada awal perkembangan pemerintahan Islam, maka berikut ini dikemukakan kasus-kasus kontemporer yang terjadi pada masyarakat Muslim di Indonesia, khususnya di lingkungan organisasi masyarakat (ormas) Islam dan masyarakat Aceh.

${ }^{11}$ Mundzir Qahaf, Manajemen Wakaf Produktif (Jakarta: Khalifa, 2005), h. 7-8.

${ }^{12}$ Paul Bohanan, Law and Warfare, h. 8. 


\section{Sengketa Wakaf di Lingkungan Ormas Muhammadiyah ${ }^{13}$}

Sehubungan dengan sengketa wakaf pada ormas Islam, akan dikemukakan kasuskasus yang terjadi di lingkungan Muhammadiyah. Ternyata, kendati Muhammadiyah dikenal sebagai ormas Islam yang relatif lebih tertib administrasi dan pengadministrasian aset wakaf di lingkungan ormas Islam ini. Majelis Wakaf adalah salah satu komponen struktur persyarikatan ini, data aset wakaf yang berada di ranting-ranting ormas ini harus memiliki data autentik yang ditempatkan pada Majelis Wakaf Pengurus Pusat persyarikatan tersebut. Meski sedemikian rupa apiknya administrasi persyarikatan tersebut, namun terjadinya sengketa wakaf tidak juga terhindarkan.

Aset tanah wakaf yang dikuasai oleh Muhammadiyah cukup banyak dan tersebar di seluruh daerah Indonesia. Dalam perjalanan waktu yang cukup lama dan mungkin karena kelalaian dalam pengelolaan wakaf dengan sebaik-baiknya sesuai dengan aturan persyarikatan tersebut, maka terjadilah sengketa wakaf meskipun jumlah sengketa tersebut relatif kecil jika dibanding dengan jumlah aset wakaf yang dimiliki ormas Islam tersebut.

\section{Sengketa Penarikan Kembali Tanah Wakaf}

Pada tanggal 30 Januari 1967 seorang dermawan di Banjarmasin mewakafkan sebidang tanah miliknya di Banjarbaru, Kalimantan Selatan sekitar 5610 m2 (30x187m) kepada Pimpinan Muhammadiyah Cabang Banjarbaru. Perwakafan dilakukan di atas segel sebagai surat tanda penyerahan hak milik yang masing-masing ditandatangani oleh kedua belah pihak, dua orang saksi, dan diketahui (ikut menandatangai) oleh Kepala Kampung Loktabat Banjarbaru. Tanah tersebut terletak di pinggir jalan raya kota Banjarbaru.

Peruntukan tanah wakaf itu dinyatakan sebagai lahan untuk pembangunan masjid, sekolah Islam, balai pengobatan, dan rumah yatim. Pihak pertama (pewakaf) menyerahkan juga surat-surat hak milik semula yang ada di tangnnya. Tidak ada syarat-syarat lainnya dalam segel penyerahan tersebut selain jenis pemanfaatan seperti di atas. Pada tahun 1968, Pimpinan Muhammadiyah Banjarbaru mulai melakukan langkah-langkah persiapan antara lain dengan membuat rencana biaya pembangunan sekolah dan pengumuman kepada warga Muhammadiyah. Tapi persiapan ini terhenti tanpa satu kemajuan yang berarti.

Selanjutnya, pada tanggal 1 Januari 1980 barulah Pimpinan Muhammdiyah cabang Banjarbaru secara resmi membentuk satu susunan Panitia pembangunan Masjid Muhammadiyah Banjurbaru dengan Surat Keputusan No. 018/PMC/Wkf-Pan/I/1980) tanggal 12 Safar $1400 \mathrm{H}=1$ Januari 1980 .

Pada tanggal 15 September 1980, si pewakaf semula menulis surat kepada Pimpinan Muhammadiyah Cabang Banjarbaru, bahwa yang bersangkutan memberi waktu satu tahun

${ }^{13}$ Adijani al-Alabij, Perwakafan Tanah di Indonesia dalam Teori dan Praktik (Jakarta: Rajawali Press, 1989), h. 84-89. 
lagi sejak diterimanya surat ini. Kalau dalam waktu satu tahun Muhammadiyah tidak berhasil merealisasikan rencananya untuk membangun masjid/madrasah dan harus selesai 100\%, maka pewakaf akan menarik kembali tanah tersebut.

Alasan utama rencana penarikan tanah ini menurut pewakaf adalah karena setelah lebih dari 13 tahun diserahkan, tanah tersebut belum berhasil dimanfaatkan oleh Muhammadiyah. Padahal maksud berwakaf adalah agar tanah tersebut dimanfaatkan sebaik-baiknya untuk masjid atau lainnya, sehingga pewakaf menerima pahalanya (amal jariah) sejak masih hidup.

Kemudian, pada tanggal 11 April 1981, Pimpinan Muhammadiyah Cabang Banjarbaru menyurati si pewakaf untuk menguraikan kembali proses penyerahan benda wakaf tersebut pada tahun 1967 dengan dalil-dalil agama. Disebutkan bahwa niat murni pewakaf sah adanya, dan telah diterima Tuhan, dan oleh karena itu tidak dapat dan tidak patut ditarik kembali. Selanjutnya, pada tanggal 20 Pebruari 1982 Pimpinan Muhammadiyah Cabang Banjarbaru menyurati kembali pewakaf, untuk memberitahukan bahwa pembangunan masjid dalam waktu dekat akan dilaksanakan.

Tetapi pada tanggal 5 Maret 1982 pewakaf mengirim surat kepada Pimpinan Muhammadiyah Cabang Banjarbaru yang menyatakan kekhawatirannya tentang perkembangan kondisi tanah wakaf yang setelah 15 tahun belum dibangun. Karena itu, pewakaf bermaksud memindahtangankan tanah wakaf itu kepada panitia lain yang sudah siap dan tersedia biayanya untuk membangun gedung untuk kepentingan syiar Islam pada tahun 1982/1983. Surat ini ditembuskan kepada Gubernur provinsi Kalimantan Selatan, Walikota Banjarbaru, Kantor Depag Kabupaten Banjar, camat Banjarbaru, dan Ka. KUA Kecamatan Banjarbaru.

Pada tanggal 20 Mei 1982 panita pembangunan Masjid ar-Rahim yang dibentuk oleh Pimpinan Muhammadiyah Cabang mengirim surat kepada Kepala Dinas PUKotamadya Banjarbaru memberitahukan rencana pembangunan masjid, dan sementara itu meminta izin membangun gudang untuk menampung bahan bangunan sumbangan masyarakat yang sudah mulai mengalir. Selanjutnya Pimpinan Muhamadiyah wilayah Kalimantan Selatan mengirim surat kepada Gubernur Kalimantan Selatan melaporkan secara kronologis tentang tanah wakaf tersebut sampai terjadinya sengketa, dengan maksud agar dapat diberi pertimbangan seperlunya.

Kendati Pimpinan Muhammadiyah Cabang Banjarbaru sudah berhasil membangun gedung sekolah di tanah wakaf tersebut, yaitu Madrasah Ibtida'iyah, Tsanawiyah, dan SMP, namun sengketa tersebut tidak dapat dituntaskan hingga tahun 1986.

\section{Sengketa Perubahan Peruntukan Wakaf}

Seorang pewakaf H. Dj. menyerahkan sebidang tanahnya yang terletak di Kelurahan Tanjung kepada Muhammadiyah Cabang Tanjung pada tahun 1970-an. Tanah wakaf tersebut diperuntukkan sebagai lahan sekolah agama. Pada sekitar tahun 1980-an sekolah yang ada diubah menjadi SD. 
Karena hal itu, HH salah seorang keluarga H. Dj (yang telah meninggal dunia) menggugat pihak Muhammadiyah agar mengembalikan tanah tersebut dengan alasan. Pertama, tujuan semula tidak dipegang oleh Muhammadiyah (dari sekolah agama diubah menjadi SD). Kedua, menurut penggugat, tanah tersebut dahulu hanya dipinjamkan saja, tidak diwakafkan untuk selama-lamanya.

Dalam hal ini, ada niat dari pihak Muhammadiyah untuk menyerahkan kembali tanah tersebut beserta bangunan yang ada di atasnya, kalau gedung baru yang dibangun oleh Muhammadiyah di lokasi lain telah selesai. Tapi penyerahan kembali ini belum terlaksana. ${ }^{14}$

\section{Sengketa Status Tanah Wakaf}

Seorang pewakaf Tm. menyerahkan sebidang tanah miliknya pada tahun 1960-an di desa Sungai Tabukan/Galagah Kecamatan Sungai Pandan kepada Muhammadiyah Cabang Sungai Tabukan. Ia mempunyai anak berinisial Drm. yang mempunyai seorang anak bernama Roh.

Setelah pewakaf (Tm) dan anaknya Drm. meninggal dunia, Roh (cucu dari pewakaf) pada tahun 1983/84 menuntut Muhammadiyah agar menyerahkan tanah yang dulu milik kakeknya tersebut kepadanya. Roh juga mengadukan Muhammadiyah kepada Kepolisian Kecamatan Sungai Pandan. Berpuluh tahun setelah tanah tersebut diwakafkan, Muhammadiyah masih memberi izin Roh untuk menanam pisang dan kelapa di atas tanah dimaksud. Jadi selama puluhan tahun Roh menikmati hasil tanaman di atas tanah wakaf tersebut. Kepala desa yang ikut serta memroses penyerahan wakaf dahulu, secara objektif membenarkan pihak Muhammadiyah. Selanjutnya adik Roh sendiri (Abd. M) berpihak kepada Muhammadiyah. Karena merasa posisinya lemah, Roh kemudian hanya menuntut ganti rugi tanaman yang dipeliharanya di atas tanah tersebut. Pihak Muhammadiyah bersedia memberikan ganti rugi, bahkan mengajak kepala desa untuk bersama-sama menaksir berapa ganti rugi yang layak diberikan kepada Roh. Tetapi adik Roh sendiri Abd. M. dengan keras melarang Muhammadiyah memberikan ganti rugi, sehingga Muhammadiyah tidak jadi memberikan ganti rugi tersebut. Akhirnya, sampai semua tanaman yang ada di atas tanah wakaf tersebut dibersihkan, Roh tidak menerima apapun, dan masalah ini begitu saja dianggap selesai. ${ }^{15}$

Ketiga contoh sengketa tanah wakaf di lingkungan Muhammadiyah tersebut selesai di luar Pengadilan Agama, walaupun pada waktu itu telah ada aturan penyelesaian sengketa wakaf dilakukan melalui Pengadilan Agama, sebagaimana diatur pada pasal 12 PP No. 28 tahun 1977.

Untuk sengketa di Banjarbaru persoalan intinya adalah "apakah boleh seseorang mewakafkan tanahnya untuk jangka waktu tertentu?" Dari berbagai riwayat dan pengertian

\footnotetext{
${ }^{14}$ Ibid.

${ }^{15}$ Ibid.
} 
yang ada yang mereka peroleh dan pahami dan kemudian membentuk produk pemikiran fikih mereka ketika itu, wakaf adalah untuk selama-lamanya. Demikian juga menurut pasal 1 ayat (1) PP. No. 28 tahun 1977 pun menyebutkan "untuk selama-lamanya". Karena itu, menurut Muhammadiyah dan pemuka agamanya bahwa tuntutan pewakaf untuk menarik kembali tanah wakafnya setelah sekian tahun berlalu, tidak sesuai dengan pengertian wakaf yang sesungguhnya diatur menurut regulasi wakaf yang ada. ${ }^{16}$

Mengenai sengketa wakaf di Tanjung, oleh nazir (dalam hal ini Muhammadiyah) terjadi perubahan peruntukan atau penggunaan lain daripada yang dimaksud dalam Ikrar Wakaf. Yang sesungguhnya menurut pasal 11 ayat (1) PP No. 28 Tahun 1977 pada dasarnya hal itu tidak boleh terjadi. Namun demikian, pihak pewakaf juga tidak dapat menarik kembali harta wakafnya karena terjadinya penyimpangan yang demikian. Pihak Muhammadiyah juga harus berjalan pada normatifnya ketika melakukan perubahan pada aspek peruntukan wakaf yang dikehendaki oleh pewakaf. Pada pasal 11 ayat (2) dinyatakan bahwa "Penyimpangan dari ketentuan tersebut dalam ayat (1) hanya dapat dilakukan terhadap hal-hal tertentu setelah terlebih dahulu mendapat persetujuan tertulis dari Menteri Agama, yakni: (a) karena tidak sesuai lagi dengan tujuan wakaf seperti diikrarkan oleh pewakaf; (b) karena kepentingan umum." Adapun sengketa tanah wakaf yang terjadi di Sungai Tabukan Alabio tersebut di atas, sebenarnya tuntutan dari cucu pewakaf tidak mempunyai dasar hukum.

\section{Sengketa Wakaf pada Masyarakat Nanggroe Aceh Darussalam}

Dalam bagian pembahasan kasus-kasus sengketa wakaf ini, yang dimaksud dengan masyarakat umum adalah peristiwa hukum dalam bidang sengketa wakaf yang terjadi di luar Ormas Islam seperti Muhammadiyah tersebut di atas. Dalam hal ini kasus yang dikemukan terbatas pada sengketa tanah wakaf yang terjadi di Aceh.

\section{Sengketa Pengesahan Status Wakaf}

Seorang pewakaf berinisal DDA mewakafakan sebidang tanah/kebun yang terletak di desa Paloh Kemukiman, SPII. Kecamatan Peusangan, Kabupaten Aceh Utara. Pada lahan tersebut dibangun masjid. Peruntukan benda wakaf yang diserahkan pada tahun 1922 itu adalah sebagai tempat pendidikan di desa Paloh tersebut. Di atas lahan wakaf tersebut dibangun masjid dan kemudian madrasah oleh masyarakat setempat. Nazir wakaf (inisial HI) adalah salah satu dari anak pewakaf dan HI memiliki anak yang berinisial JH. Setelah nazir (HI) meninggal dunia putranya, JH mengklaim bahwa kakeknya tidak pernah mewakafkan kebun tersebut. Pada tanggal 31 Juli 1984 JH membuat pernyataan yang dituangkan dalam bentuk surat tertulis dan disampaikan kepada masyarakat desa setempat. Ia mengemukakan argumentasinya bahwa tanah tersebut tidak terdaftar sebagai tanah wakaf di KUA setempat.

${ }^{16}$ Ibid., h. 114. 
Merespon aksi JH tersebut, MH dan beberapa warga masyarakat lainnya mengajukan permohonan ke Pengadilan Agama Bireun untuk mengesahkan wakaf tanah yang telah diserahkan oleh DDA. Dengan keterangan saksi-saksi, akhirnya majelis hakim Pengadilan Agama Bireun memandang bahwa permohonan MH dan kawan-kawan dapat dikabulkan. Akhirnya, status tanah/kebun itu disahkan sebagai objek wakaf.

Karena tidak puas, pihak yang dikalahkan mengajukan banding ke Pengadilan Tinggi Agama (PTA) Banda Aceh. PTA mengeluarkan putusan sela yang isi pokoknya: (a) menerima permohonan banding pihak pembanding, dan (b) memerintahkan Pengadilan Agama Bireun untuk membuka kembali sidang perkara wakaf tersebut.

Pada tahap berikutnya, PTA Banda Aceh menetapkan Putusan Nomor 20 Tahun 1985 mengenai perkara wakaf yang diajukan banding dengan keputusan bahwa wakaf tanah/ kebun yang diserahkan oleh DDA adalah sah. Karena itu, putusan PTA Banda Aceh menguatkan putusan Pengadilan Agama Bireun.

Karena tidak puas juga para pihak yang kalah akhirnya mengajukan kasasi ke Mahkamah Agung. Pada tanggal 14 Desember 1988, Mahkamah Agung mengeluarkan putusan Nomor 49K/AG/1987, yang isinya menolak permohonan kasasi para pemohon. Hakitu berarti Mahkamah Agung menguatkan Putusan Pengadilan Tinggi Agama Banda Aceh dan sekaligus juga menguatkan putusan Pengadilan Agama Bireun. ${ }^{17}$

\section{Sengketa Penukaran Tanah Wakaf}

HW bersama kawan-kawannya pada tanuh 1926 mewakafkan sebidang tanah yang terletak di desa Tanjong Ara, Kecamatan Tanah Jambo Aye, Kabupaten Aceh Utara untuk kuburan dan tempat pendidikan agama Islam.

Pada tahun 1971, MNA dan kawan-kawan (dari desan Tanjong Ara) menukarkan tanah wakaf tersebut dengan sawah milik TA. Tanah wakaf yang berupa sawah dikelola oleh masyarakat, sementara tanah wakaf berupa kebun dikelola oleh TA. Tetapi, TA tidak memfungsikan tanah tersebut sesuai dengan tujuan wakaf karena menurutnya tanah tersebut bukan tanah wakaf, tapi tanah Musara. Setelah memeriksa bukti dan saksi-saksi, Pengadilan Agama Lhoksukon menetapkan: (a) mengabulkan gugatan para penggugat, dan (b) menetapkan bahwa tanah terperkara adalah tanah wakaf dari HW dan kawan-kawan.

Karena tidak puas dengan putusan Pengadilan Agama Lhoksukon, pihak yang dikalahkan melakukan banding ke PTA Banda Aceh. Setelah dilakukan pemeriksaan, PTA memutuskan bahwa: (a) menghukum tergugat (pada pengadilan tingkat pertama) untuk menyerahkan tanah wakaf tersebut kepada tergugat sesuai dengan Putusan Pengadilan Agama Nomor 1/P/90/PALsk tanggal 21 Pebruari 1990, dan (b) menghukum pembanding untuk membayar biaya perkara.

\footnotetext{
${ }^{17}$ Jaih Mubarok, Wakaf Produktif, h. 181-182.
} 
Karena tidak puas juga dengan putusan PTA tersebut, pihak yang dikalahkan mengajukan kasasi ke Mahkamah Agung. Setelah melakukan pemeriksaan, Mahkamah Agung menetapkan keputusan yang isinya menguatkan dua putusan sebelumnya, yaitu menghukum tergugat (pada pengadilan tingkat pertama) untuk menyerahkan tanah wakaf kepada masyarakat desa Tanjong Ara dalam keadaan kosong. ${ }^{18}$

\section{Penutup}

Wakaf yang merupakan lembaga kebajikan dan amanah (charity and trust) dalam Islam tidak terlepas dari dimensi sosial, dan memang implikasinya adalah untuk kesejahteraan sosial. Bicara tentang kesejahteraan tidak terlepas dari suatu nilai, baik nilai spiritual maupun nilai sosial dan nilai ekonomis. Dalam masyarakat ada proses sosial yang mana kompetisi terhadap suatu nilai merupakan bagian dari proses sosial tersebut. Ketika kompetisi menjadi intens akan dapat berlanjut mengalami eskalasi yang menjadi sengketa (dispute). Dengan demikian dalam sejarah hukum Islam ternyata masyarakat Muslim tidak terhindar dari proses sosial tersebut, sehingga sumber nilai yang ada pada wakaf telah menggerakkan tindakan mereka dalam berkompetisi dan muncul menjadi sengketa perwakafan dalam masyarakat Muslim.

\section{Pustaka Acuan}

Abbas, Syahrizal. Mediasi dalam Perspektif Hukum Syariah, Hukum Adat, dan Hukum Nasional. Jakarta: Kencana Prenada Media Group, 2009.

Al-Alabij, Adijani. Perwakafan Tanah di Indonesia dalam Teori dan Praktek. Jakarta: Rajawali Press, 1989.

Aliyah, Samir. Nizhâm al-Daulah wa al-Qadhâ'wa al-'Urffĩal-Islâm. Jakarta Timur: Khifa, 2004.

Al-Mugniyah, Muhammad Jawad. Fiqh Lima Mazhab. Jakarta: Lentera 1996.

Aripin, Jaenal. Peradilan Agama dalam Bingkai Reformasi Hukum di Indonesia. Jakarta: Prenada Media Group, 2008.

Bohanan, Paul. Law and Warfare, Studies in the Anthroplogy of Conflict. New York: The Natural History Press, 1967.

French, Rebecca Redwood. "Law and Anthropology," dalam Dennis Patterson (ed.), A Comparison to Philosophy of Law and Legal Theory. Oxford: Blackwell Publishing Ltd., 2003.

Friedman, Lawrance M. Law and Society; An Introduction. New Jersey: Standford University, 1977.

Hamami, Taufik. Perwakafan Tanah dalam Politik Hukum Agraria Nasional. Jakarta: Tatanusa, 2003.

${ }^{18}$ Ibid, h. 18. 
Hamami, Taufik. Perwakafan Tanah dalam Politik Hukum Agraria Nasional. Jakarta: Tatanusa, 2003.

Hassan, Sharifah Zaleha Syed \& Sven Cederroth. Managing Marital Disputes in Malaysia; Islamic Mediators and Conflict Resolution in the Syariah Courts. Richmond: Curzon Press, 1997.

Al-Kabisi, Muhammad Abid Abdullah. Ahkkâm al-Waqffí al-Syarî‘ah al-Islâmizah. Jakarta: Dompet Dhuafa dan IIMan, 2004.

Mannan. Sertifikat Wakaf Tunai: Sebuah Inovasi Instrumen Keuangan Islam. Jakarta Selatan: Ciber-PKKTI-UI,2001.

Mudjieb, M. Abdul. Kamus Istilah Fiqh. Jakarta: Pustaka Firdaus, 1994.

Muhammad Abid Abdullah al-Kabisi. Ahkâm al-Waqffí al-Syarî‘ah al-Islâmiyah. Jakarta: Dompet Dhuafa dan IIMan, 2004.

Munawwar, Said Agil Husin. Hukum Islam \& Pluralitas Sosial. Jakarta: Penamadani, 2005.

Qahaf, Mundzir. Manajemen Wakaf Produktif. Jakarta: Khalifa, 2005.

Rofiq, Ahmad. Hukum Islam di Indonesia. Jakarta: RajaGrafindo Persada, 2000. 